\title{
Effect of Foliar Application of Micronutrients on Nutrient Content of Gerbera
}

\author{
Mukesh Kumar Sahu ${ }^{1}$, T. Kushram ${ }^{2}$, A. Kulmitra ${ }^{3}$, R. Kumar ${ }^{4}$ and N. Sahu ${ }^{5}$ \\ ${ }^{1}$ Department of Floriculture and Landscape Architecture, COA, IGKV Raipur, \\ Chhattisgarh (492012) India \\ ${ }^{2}$ Department of Entomology, COA, IGKV Raipur, Chhattisgarh, (492012) India \\ ${ }^{3}$ Department of Plant Pathology, COA, IGKV Raipur, Chhattisgarh, (492012) India \\ ${ }^{4}$ Department of Plant Breeding, COA, IGKV Raipur, Chhattisgarh, (492012) India \\ ${ }^{5}$ Department of Soil Science, COA, IGKV Raipur, Chhattisgarh, (492012) India \\ *Corresponding author
}

\section{A B S T R A C T}

\begin{tabular}{|l|}
\hline Ke y w o r d s \\
$\begin{array}{l}\text { Foliar Application, } \\
\text { Gerbera, Leaf } \\
\text { Content, } \\
\text { Micronutrients. }\end{array}$ \\
\hline Article Info \\
$\begin{array}{l}\text { Accepted: } \\
\text { 20 February } 2017 \\
\text { Available Online: } \\
\text { 10 March } 2017\end{array}$ \\
\hline
\end{tabular}

\section{Introduction}

Flowers have been closely associated with Indian culture from the Vedic times. Floriculture has become profitable industry in many parts of the globe. It is a fast growing sector of horticulture in the world growing around 10 - 12 percent per annum. Gerbera (Gerbera jamesonii) belongs to the family compositae. It is commonly known as Transvaal Daisy, Barberton Daisy or African daisy and produces very attractive flowers.

It is an important commercial flower grown throughout the world in a wide range of climatic conditions. It ranks fourth in the international cut flower market and a popular cut flower in Holland, Germany and USA (Choudhary and Prasad, 2000 and Sujatha et $a l ., 2002)$. Gerbera are broadly and commonly used as cut flowers for flowery array, interior decoration and gifts for particular occasion, wedding ceremony bouquet. The daisy like flowers are in wide range of colours including yellow, orange, cream, white, pink, brick- red, scarlet, salmon, maroon, terracotta and various other intermediate shades.

Micronutrients play vital roles in the growth and development of plants, due to their 
stimulatory and catalytic effects on metabolic processes and ultimately on flower yield and quality (Khosa et al., 2011). Micronutrients are to be necessarily taken up by the plants from soil or supplemented through foliar application for good growth and yield of crops and maximizing the efficient use of applied $\mathrm{N}, \mathrm{P}$ and $\mathrm{K}$. In the absence of micronutrients, the plants are known to suffer from physiological disorders which eventually lead to imbalanced growth and low yield of flower. The nutrient removal is very high under protected condition due to intensive cultivation of the crop and hence its nutrient requirements have to be carefully monitored through plant/leaf analysis for high productivity and quality.

\section{Materials and Methods}

The present study was carried out under protected condition at the Center of Excellence on Protected Cultivation, Indira Gandhi Krishi Vishwavidyalaya, Raipur (Chhattisgarh), during the year 2015-2016. The experiment was laid out in Completely Randomized Design (CRD). With thirteen treatment combinations and three replications, the micronutrients were sprayed at 30 days interval after planting. Observation recorded were recorded on macro-nutrients content i.e. NPK (\%), micro-nutrients content i.e. iron (ppm), manganese (ppm), zinc (ppm). Nitrogen was estimated by Naessler's Reagent Method as per standard procedure and phosphorus was determined by VanadoMolybdo phosphoric acid yellow colour method. Potassium was estimated by Flame Photometer Method, Zinc, Manganese and Iron in the digested plant samples determined with the help of atomic absorption spectrophotometer (AAS). The recommended package of practices was followed to raise healthy crop.

The treatments comprised of different micronutrients with different concentration solely or in combination viz, $\mathrm{ZnSO}_{4}(0.2 \%)$, $\mathrm{ZnSO}_{4}(0.4 \%), \mathrm{ZnSO}_{4}(0.6 \%), \mathrm{MnSO}_{4}(0.2 \%)$, $\begin{array}{lllll}\mathrm{MnSO}_{4} & (0.4 \%), & \mathrm{MnSO}_{4} & (0.6 \%), & \mathrm{FeSO}_{4}\end{array}$ $(0.1 \%), \mathrm{FeSO}_{4}(0.3 \%), \mathrm{FeSO}_{4}(0.5 \%), \mathrm{ZnSO}_{4}$ $(0.2 \%)+\mathrm{MnSO}_{4}(0.2 \%)+\mathrm{FeSO}_{4}(0.1 \%)$, $\mathrm{ZnSO}_{4}(0.4 \%)+\mathrm{MnSO} 4(0.4 \%)+\mathrm{FeSO} 4$ $(0.3 \%), \mathrm{ZnSO}_{4}(0.6 \%)+\mathrm{MnSO}_{4}(0.6 \%)+$ $\mathrm{FeSO}_{4}(0.5 \%)$, Control (water spray).

\section{Results and Discussion}

On data presented in Table 1 it is evident that the nitrogen content in leaf was recorded highest $(2.37 \%)$ in the treatment $\mathrm{T}_{10}\left[\mathrm{ZnSO}_{4}\right.$ $\left.(0.2 \%)+\mathrm{MnSO}_{4}(0.2 \%)+\mathrm{FeSO}_{4}(0.1 \%)\right]$, which was statistically similar with the treatment $\mathrm{T}_{6} \quad(2.33 \%), \quad \mathrm{T}_{11} \quad(2.31 \%), \quad \mathrm{T}_{9}$ $(2.24 \%), \mathrm{T}_{4}(2.23 \%), \mathrm{T}_{12}(2.23 \%)$, Whereas, highest phosphorous content in leaf $(0.28 \%)$ was observed in treatment $\mathrm{T}_{10}\left[\mathrm{ZnSO}_{4}(0.2 \%)\right.$ $\left.+\mathrm{MnSO}_{4}(0.2 \%)+\mathrm{FeSO}_{4}(0.1 \%)\right]$, which was statistically similar with the treatment $\mathrm{T}_{3}$ $(0.25 \%), \mathrm{T}_{9}(0.24 \%)$ and $\mathrm{T}_{11}(0.24 \%)$, highest potassium content in leaf $(2.45 \%)$ was found in treatment $\mathrm{T}_{10}\left[\mathrm{ZnSO}_{4}(0.2 \%)+\mathrm{MnSO}_{4}\right.$ $\left.(0.2 \%)+\mathrm{FeSO}_{4}(0.1 \%)\right]$, which was followed by $\mathrm{T}_{9}(2.31 \%)$. The lowest available of nitrogen, phosphorous and potassium $(2.04 \%),(0.16 \%)$ and $(1.83 \%)$, respectively in leaf was found in treatment $\mathrm{T}_{13}$.

In case of available micronutrients (zinc, manganese and iron) content in leaf (Table 2), the highest zinc content in leaf (98.43 ppm), was recorded in the treatment $\mathrm{T}_{10}\left[\mathrm{ZnSO}_{4}\right.$ $\left.(0.2 \%)+\mathrm{MnSO}_{4}(0.2 \%)+\mathrm{FeSO}_{4}(0.1 \%)\right]$, which was followed by the treatment $\mathrm{T}_{11}$ (96.17 ppm) and $\mathrm{T}_{3}(93.50 \mathrm{ppm})$. However, minimum zinc content $(61.10 \mathrm{ppm})$, in leaf was recorded in treatment $\mathrm{T}_{13}$. Maximum manganese content in leaf $(99.53 \mathrm{ppm})$ was observed in treatment $\mathrm{T}_{10}\left[\mathrm{ZnSO}_{4}(0.2 \%)+\right.$ $\left.\mathrm{MnSO}_{4}(0.2 \%)+\mathrm{FeSO}_{4}(0.1 \%)\right]$, which was statistically similar with the treatment $\mathrm{T}_{6}$ (92.40 ppm) and $\mathrm{T}_{11}(92.32 \mathrm{ppm})$. 
Table.1 Available nitrogen, phosphorous and potassium content in gerbera leaf (\%)

\begin{tabular}{|l|c|c|c|}
\hline Treatment & N & P & K \\
\hline $\mathrm{ZnSO}_{4}(0.2 \%)$ & 2.11 & 0.17 & 1.97 \\
\hline $\mathrm{ZnSO}_{4}(0.4 \%)$ & 2.22 & 0.21 & 2.09 \\
\hline $\mathrm{ZnSO}_{4}(0.6 \%)$ & 2.16 & 0.25 & 2.16 \\
\hline $\mathrm{MnSO}_{4}(0.2 \%)$ & 2.23 & 0.15 & 2.07 \\
\hline $\mathrm{MnSO}_{4}(0.4 \%)$ & 2.21 & 0.22 & 2.18 \\
\hline $\mathrm{MnSO}_{4}(0.6 \%)$ & 2.33 & 0.23 & 2.23 \\
\hline $\mathrm{FeSO}_{4}(0.1 \%)$ & 2.12 & 0.17 & 2.25 \\
\hline $\mathrm{FeSO}_{4}(0.2 \%)$ & 2.16 & 0.23 & 2.18 \\
\hline $\mathrm{FeSO}_{4}(0.3 \%)$ & 2.24 & 0.24 & 2.31 \\
\hline $\mathrm{ZnSO}_{4}(0.2 \%)+\mathrm{MnSO}_{4}(0.2 \%)+\mathrm{FeSO}_{4}(0.1 \%)$ & 2.37 & 0.28 & 2.45 \\
\hline $\mathrm{ZnSO}_{4}(0.4 \%)+\mathrm{MnSO}_{4}(0.4 \%)+\mathrm{FeSO}_{4}(0.3 \%)$ & 2.31 & 0.24 & 2.30 \\
\hline $\mathrm{ZnSO}_{4}(0.6 \%)+\mathrm{MnSO}_{4}(0.6 \%)+\mathrm{FeSO}_{4}(0.5 \%)$ & 2.23 & 0.23 & 2.19 \\
\hline $\mathrm{Control}_{(\text {water spray })}$ & 2.04 & 0.16 & 1.83 \\
\hline S. Em & 0.05 & 0.01 & 0.05 \\
\hline CD at 5\% & 0.14 & 0.04 & 0.14 \\
\hline
\end{tabular}

Table.2 Available zinc, manganese and iron content in gerbera leaf (ppm)

\begin{tabular}{|l|c|c|c|}
\hline Treatment & Zn & Mn & Fe \\
\hline $\mathrm{ZnSO}_{4}(0.2 \%)$ & 69.92 & 67.47 & 211.87 \\
\hline $\mathrm{ZnSO}_{4}(0.4 \%)$ & 78.61 & 74.10 & 219.00 \\
\hline $\mathrm{ZnSO}_{4}(0.6 \%)$ & 93.50 & 78.57 & 230.98 \\
\hline $\mathrm{MnSO}_{4}(0.2 \%)$ & 65.95 & 75.83 & 220.39 \\
\hline $\mathrm{MnSO}_{4}(0.4 \%)$ & 72.99 & 81.80 & 231.23 \\
\hline $\mathrm{MnSO}_{4}(0.6 \%)$ & 86.47 & 92.40 & 243.55 \\
\hline $\mathrm{FeSO}_{4}(0.1 \%)$ & 76.17 & 74.67 & 245.33 \\
\hline $\mathrm{FeSO}_{4}(0.2 \%)$ & 78.31 & 79.24 & 259.83 \\
\hline $\mathrm{FeSO}_{4}(0.3 \%)$ & 81.91 & 80.17 & 286.69 \\
\hline $\mathrm{ZnSO}_{4}(0.2 \%)+\mathrm{MnSO}_{4}(0.2 \%)+\mathrm{FeSO}_{4}(0.1 \%)$ & 98.43 & 99.53 & 291.97 \\
\hline $\mathrm{ZnSO}_{4}(0.4 \%)+\mathrm{MnSO}_{4}(0.4 \%)+\mathrm{FeSO}_{4}(0.3 \%)$ & 96.17 & 92.32 & 287.61 \\
\hline $\mathrm{ZnSO} 4(0.6 \%)+\mathrm{MnSO}_{4}(0.6 \%)+\mathrm{FeSO}_{4}(0.5 \%)$ & 91.88 & 90.57 & 252.40 \\
\hline Control $($ water spray) & 61.10 & 66.10 & 194.73 \\
\hline S. Em & 2.18 & 2.54 & 1.84 \\
\hline CD at 5\% & 6.33 & 7.39 & 5.35 \\
\hline
\end{tabular}


Fig.1 Available nitrogen, phosphorous and potassium content in gerbera leaf (\%)

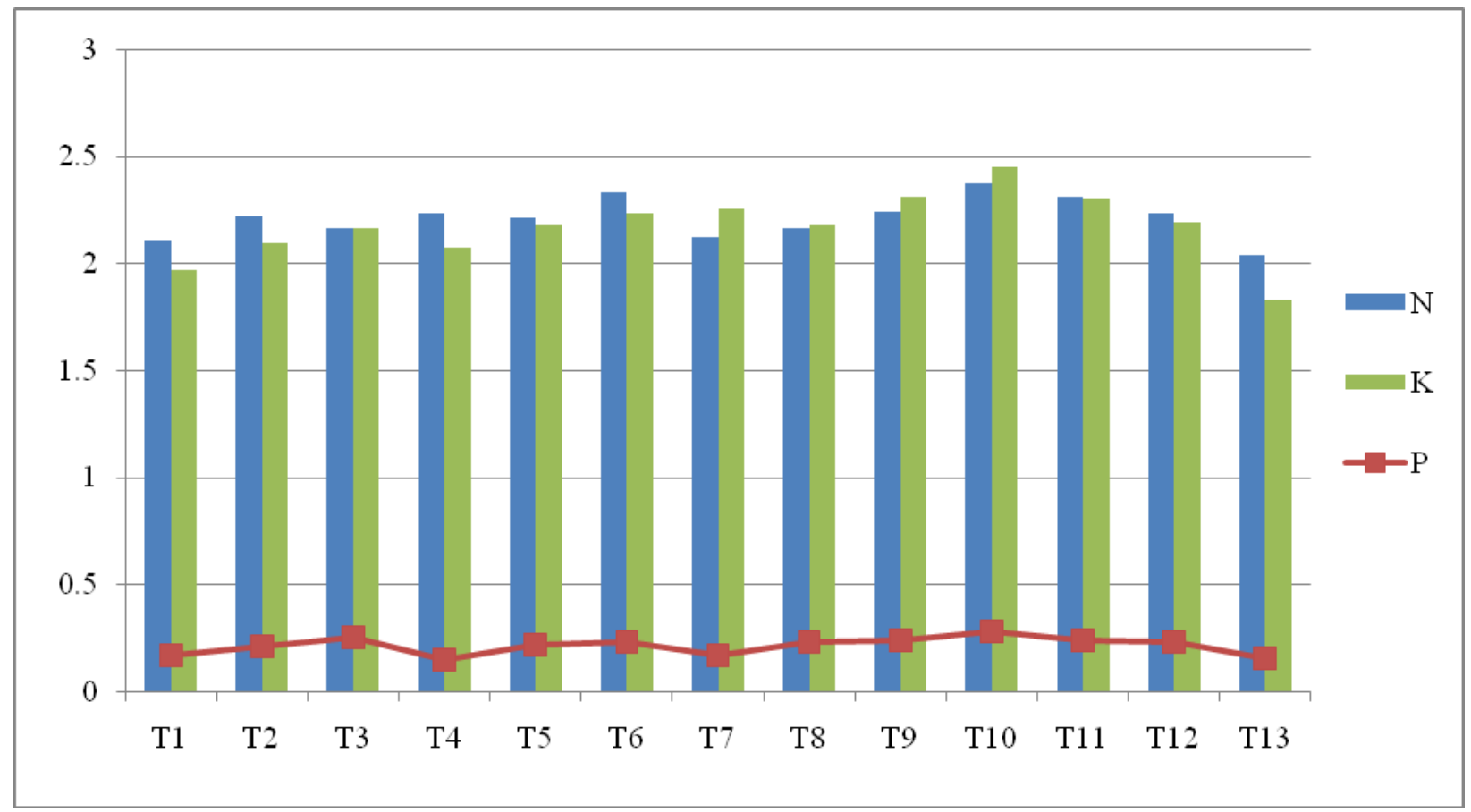

Fig.2 Available zinc, manganese and iron content in gerbera leaf (ppm)

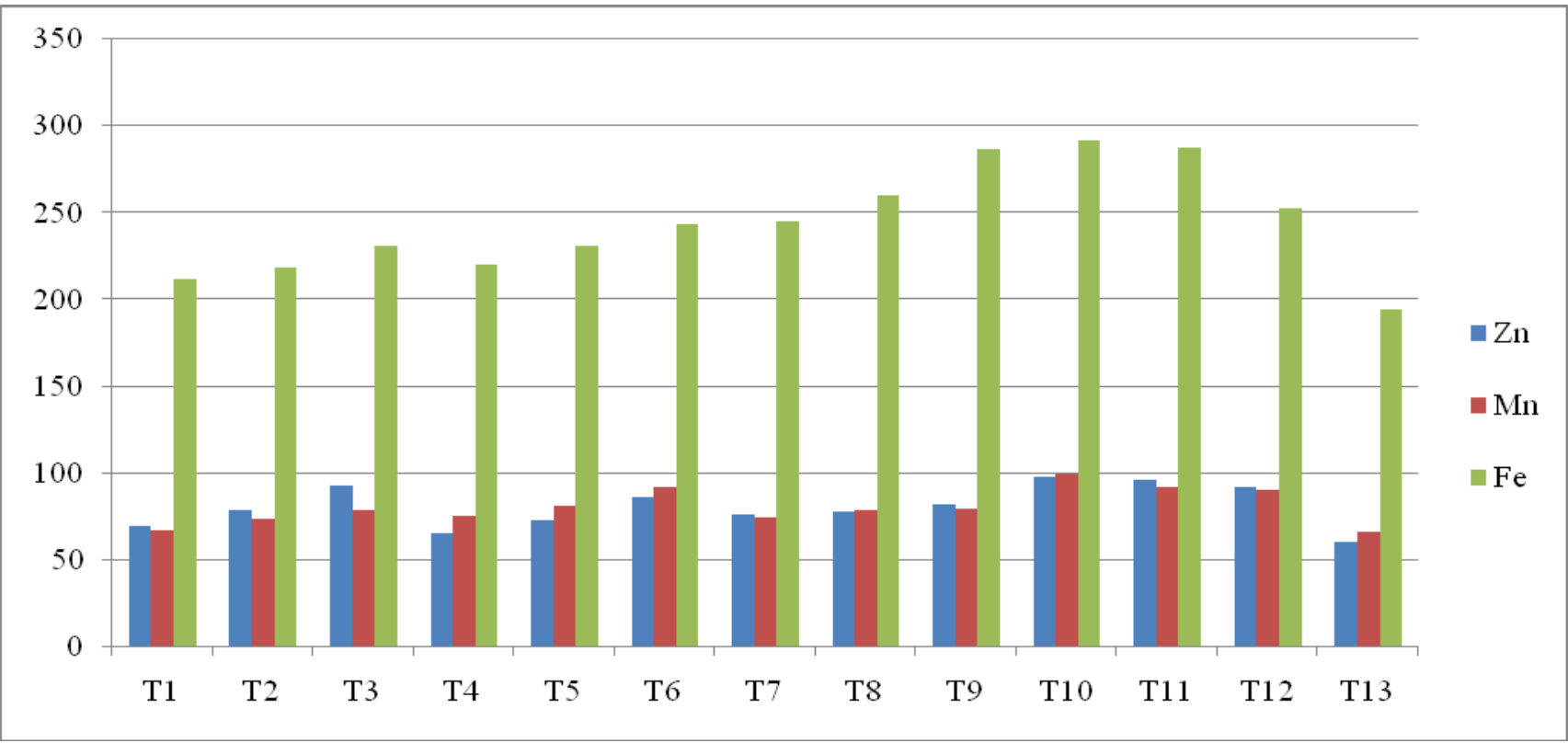

However, lowest content of manganese (66.10 ppm) was recorded in treatment $\mathrm{T}_{13}$. Maximum iron content in leaf (291.97 ppm) was found in treatment $\mathrm{T}_{10}\left[\mathrm{ZnSO}_{4}(0.2 \%)+\right.$ $\left.\mathrm{MnSO}_{4}(0.2 \%)+\mathrm{FeSO}_{4}(0.1 \%)\right]$, and was statistically similar with $\mathrm{T}_{11}(287.61 \mathrm{ppm})$ and $\mathrm{T}_{9}$ (286.69 ppm). However, lowest available iron in leaf (194.73 ppm) was found in treatment $\mathrm{T}_{13}$ 
Foliar application of the iron may have improves protein synthesis and more chlorophyll production resulting in higher uptake of $\mathrm{N}, \mathrm{P}, \mathrm{K}$, as well as $\mathrm{Zn}, \mathrm{Mn}$ and $\mathrm{Fe}$. The Mn content is also essential for nitrogen metabolism and better assimilation of carbon dioxide in photosynthesis. Due to better plant growth by the application of micronutrients might be resulted in significant increase in available nitrogen, phosphorous potassium zinc, manganese and iron in leaf, Soni et al., (2010) in gerbera.

\section{References}

Anjaneyulu, K. 2008. Diagnostic leaf nutrient norms and identification of yield limiting nutrients in gerbera grown under protected conditions using DRIS. Indian $J$. Horticul., 65(2): 176-179.

Choudhary, Prasad. 2000. Effect of potassium and calcium concentrations in the nutrient solution on growth and nutrient uptake of rose plants. Int. J. Sci. Res., 69(4): 606608.

Khosa, S.S., Younis, A., Yameen, S., Riaj, A. 2011. Effect of foliar application of micro nutrients on growth and flowering of gerbera (Gerbera jamesonii). AmericanEurasian J. Agri. Environ. Sci., 11(5): 736-757.

Soni, S.S., Godara, A.K., Sehrawat, S.K. and Goyal, R.K. 2010. Effect of foliar application of micronutrient on nutrients and chlorophyll content of gerbera var. Winter Queen. Haryana J. Ornamental Horticulture, 39(1/2): 153-154.

Sujatha, K., Gowda, J.V.N. and Khan, M.M. 2002. Effects of different fertigation levels on gerbera under low cost greenhouse. $J$. Ornamental Horticulture, 5(1): 54-59.

\section{How to cite this article:}

Mukesh Kumar Sahu, T. Kushram, A. Kulmitra, R. Kumar and N. Sahu. 2017. Effect of Foliar Application of Micronutrients on Nutrient Content of Gerbera. Int.J.Curr.Microbiol.App.Sci. 6(3): 2123-2127. doi: https://doi.org/10.20546/ijcmas.2017.603.242 